JUSTISI | 2018

\title{
Tanggung Gugat Pengangkut Minyak Terhadap Pencemaran Lingkungan
}

\author{
Marthin Sahertian \\ Fakultas Hukum, Universitas Muhammadiyah Sorong \\ Email : M.Sahertian12@gmail.com
}

\begin{abstract}
Abstrak
Peneltian ini bertujuan untuk menganalisis bagimana ketentuan kapal pengangkut minyak menurut Undang-Undang Nomor 17 Tahun 2008 tentang Pelayaran dan bagaimana kewajiban pengangkut membayar ganti rugi akibat pencemaran laut. Metode penelitian yang digunakan dalam penelitian ini adalah metode yuridis normatif, artinya suatu penelitian yang bertumpu pada peraturan perundang-undangan dengan ditopang studi kepustakaan relevan dengan permasalahan dibahas kemudian dianalisis dan disimpulkan dalam penulisan. Hasil penelitian ini menunjukan bahwa salah pencemaran laut akibat tumpahan minyak atau limbah dari kapal, salah satunya adalah kurangnya tanggung jawab pemilik kapal terhadap pemeunuhan persyaratanpersyaratan teknis baik dari segi fisik kapal maupun ketentuan administrasi sesuai peraturan perundang-undangan yang berlaku. Akibat pencemaran laut yang berasal dari kapal maupun kegiatan ekplorasi pengeboran lepas pantai dalam bentuk meinyak melalui pengangkut oleh kapal pengangkut minyak, konsekuensinya adalah perlunya tanggung jawab terhadap akibat yang ditimbulkan karena itu, Undang-Undang telah mengatur sejumlah sanksi yang harus ditanggung oleh setiap penyebab terjadinya pencemaran laut baik penyelenggara pengangkutan minyak maupun pemilik kapal pengangkut minyak. Rekomendasi dari penelitian ini adalah diperlukan pengaturan yang lebih cermat, lebih rinci agar tidak bermakna ganda serta pengawasan secara kontinyu agar semua kapal pengangkut minyak dapat mematuhi syarat-syarat teknis dan syarat-syarat formal, serta perlu diadakan perkembangan aturan yang mampu mengimbangi kemajuan teknologi.
\end{abstract}

Kata Kunci : Hukum Laut, Hukum Lingkungan, Pencemaran Lingkungan

\section{PENDAHULUAN}

Suatu hal yang dapat dipahami bahwa aktifitas angkutan minyak bumi dalam jumlah besar merupakan suaru usaha yang tergolong mengandung resiko yang teramat besar dan berbahaya (extra hazardous activity). Juga dipahami bahwa tumpahan minyak dapat menimbulkan akibat yang sangat parah terhadap lingkungan maritim maupun kerugian yang akibatnya dapat dirasakan segera setelah tumpahan 
minyak terjadi sampai kepada bentuk kerugian jangka panjang yang akibatnya baru akan Nampak setelah dilampaui suatu jangka waktu tertentu.

Menyadari pentingnya masalah perlindungan laut dari aktifitas manusia yang dapat menimbulkan pencemaran, masyarakat Internasional menginginkan adanya suatu ketentuan hukum yang meletakkan hak dan kewajiban Negara-negara dalam masalah lingkungan laut ini. Pencemaran laut oleh minyak barulah ditangani secar khusus dalam skala internasional pada tahun 1954 dalam suatu konferensi di London yang diselenggarakan atas inisiatif IMCO (Intergovernmental Maritime Consultatif Organization) yang sekarang diubah menjadi IMO (International Maritime Organization), yakni suatu bdan khusus yang mengurus bidang maritim.

Hal yang sangat penting untuk diperhatikan oleh Indonesia dalam masalah terjadinya pencemaran laut oleh minyak adalah kerawanan selat Malaka-singapura yang merupakan lalu lintas paling penting dan ramai oleh karena selat ini memberikan rute laut singkat antara lautan Hindia (lewat Andaman) dan laut pasifik (lewat laut Cina Selatan), selat Malaka; dan Singapura ini menjadi urat nadi dalam perdagangan melalui laut, sejak tahun 1950 selat tersebut sangat penting dalam pengangkutan bahan bakar minyak yang jumlahnya selalu meningkat.

Dalam rangka mewujudkan suatu sistem perhubungan nasional yang terpadu maka pola pengembangan kegiatan sub sektor perhubungan laut memegang peranan yang sangat penting dalam menunjang pembangunan sektor lainnya, sepeti perdagangan, pariwisata, perindustrian, pertahanan, pertanian, transmisi, lingkungan hidup, dan sebagainya. Dalam rangka mewujudkan suatu sistem perhubungan nasional yang terpadu maka pola pengembangan kegiatan sub sektor perhubungan laut dikelompokkan menjadi sub sistem angkutan laut, sub sistem ke pelabuhan, dan sub sistem keselamatan pelayaran. Pelaksanaan ketiga sub sistem tersebut diselenggarakan secara terpadu dan saling mendukung, sehingga terwujud angkutan laut yang handal, aman, nyaman, tertib dan terjangkau oleh kemampuan masyarakat ekonomi. 
Indonesia dalam mengatur bagaimana lalu lintas perairan serta pelaksanaan penangan pencemaran laut didasakran pada beberapa aturan yaitu sebagai berikut ; (1) Internasional Convention on Civil Liability for Oil Pollution Damage 1969 (CLC1969) yang telah diratifikasi denga Keputusan Presiden Nomor 18 tahun 1978; (2) International Convention of The Establishment of and International Fund for Compensation for Oil Pollution Damage 1971 (fund.1971) yang telah diratifikasi dengan Keputusan Presiden Nomor 19 tahun 1978; (3) International Convention for safety of Life at Sea (solas) 1974 yang telah diratifikasi dengan Keputusan Kepresiden Nomor 65 tahun 1980; (4) International Conventronarie Prevention of Pollution from Ship 1973 and Protocol 1978 (MARPOL 73/78) yang telah diratifikasi dengan Keputusan Presiden Nomor 46 Tahun 1986; (5) Undang-Undang nomor 17 Tahun 1985 tentang Ratifikasi Konvensi PBB Hukum Laut 1982 (LN 1985/76; TLN Nomor 3319) 31 Desember 1985 Jakarta; (6) Undang-Undang Nomor 5 Tahun 1983 tentang Zona Ekonomi Ekslusif Indonesia (Lembaran Negara Republik Indonesia Tahun 1983 nomor 44, Tambahan Lembaran Negara Republik Indonesia Nomor 3260) diundangkan dan disahkan di Jakarta pada tanggal 18 Oktober 1983; (7) Peraturan Pemerintah (PP) Nomor 19 tahun 1994 yang diperhabarui dengan PP Nomor 121995 dan diperbaharui kembali dengan PP Nomor 18 Tahun 1999 tanggal 27 Februari 1999 yang dikuatkan lagi melalui Peraturan Pemerintah Nomor 74 tahun 2001 tanggal 26 November 2001 tentang Pengelolaan Limbah B3; (8) UndangUndang Nomor 17 tahun 2008 tentang Pelayaran (Lembaran Negara Republik Indonesia Tahun 2008 Nomor 64) disahkan dan diundangkan pada tanggal 7mei 2008; (9) Peraturan Pemerintah (PP) Nomor 21 Tahun 2010 tentang Perlindungan Lingkungan Maritim.

Dalam rangka penangan pencegahan dan penanggulangan pencemaran laut, maka telah dirumuskan pokok-pokok kebijaksanaan Sub sektor Perhubungan Laut, dalam Bidang Pencegahan Pencemaran yaitu; (1) Kapal-kapal yang beroperasi di perairan Indonesia baik kapal Indonesia maupun kapal asing wajib dilengkapi dengan peralatan pencegahan pencemaran laut; (2) Awak kapal harus memiliki pengetahuan 
dan keterampilan dalam kaitannya dengan penegahan dan penanggulangan pencemaran laut'kepal-kapal tangki minyak dengan ukuran tertentu diwajibkan mengasuransikan tanggung jawabnya atas pencemaran laut yang ditimbulkan akibat kecelakaan kapal; (3) Kapal-kapal tanki menyak dengan ukuran tertentu diwajibkan mengasuransikan tanggung jawab atas pencemaran laut yang diimbulkan akibat kecelakaan kapal; (4) Pembangunan pelabuhan dilaksanakan berdasarkan persyaratan teknis ke pelabuhan dengan memperhatikan kelestarian lingkungan antara lain pelabuhan-pelabuhan dilengkapi dengan sarana penampungan limbah atau bahan buangan lain dari kapal; (5) Mencegah atau memperkecil kecelakaan-kecelakaan kapal dengan cara meningkatkan penerapan ketentuan-ketentuan di bidang keselamatan kapal dan mengikuti sarana bentuk navigasi pelayaran.

Sementara itu penanggulangan pencemaran laut yaitu; (1) Menetapkan pola penanggulangan pencemaran laut terutama oleh minyak pada tingkat local, interlokal, nasional serta regional; (2) Menciptakan pelaksanaan penanggulangan yang cepat dan tepat dengan cara meningkatkan koordinasi dengan instansi-instansi yang terkait; (3) Meningkatkan kesiapan penanggulangan pencemaran dengan upaya kemampuan tenaga yang profesional.

Selain itu, pemasangan peralatan pencegahan pencemaran diatas kapal diatur dalam Peraturan menteri Perhubungan Nomor 4 tahun 2005 tentang Pencegahan Pencemaran oleh minyak dari kapal-kapal. Pun juga pengetahuan dan keterampilan anak buah kapal yang berkaitan dengan pencegahan dan penanggulangan pencemaran dilakukan dengan berpedoman pada ketentuan International Convention Standar of training Certification and Watch keeping 1978. Dalam kaitannya dengan kelestarian lingkungan laut maka terhadap pelabuhan yang sudah ada dan akan dibangun wajib dibuatkan studi AMDAL.disamping itu berdasarkan Keputusan Menteri Perhubungan Nomor KM 215/AL-506/PHE-87 tentang Pengadaan Fasilitas Penampungan Limbah dari kapal. 
Menyadari akan dampak negatif atas pencemaran laut akibat tumpahan bahan pencemar seperti minyak atau bahan cair beracun, begitu pula adanya tumpahan minyak dalam jumlah besar akibat kecelakaan kapal atau diarea sekitar pengeboran minyak lepas pantai, maka diperlukan langkah penanggulangan yang cepat dan tepat. Berdasarkan uraian diatas, maka dapat dikemukakan rumusan masalah sebagai berikut; (1) Bagaimana Ketentuan Manajemen Keselamatan Pengoperasian Kapal, Pencegahan dan Perlindungan Maritim Akibat Pencemaran Minyak Kapal?; (2) Bagaimana Sistem Pertanggung-Jawaban dan Perjanjian Ganti Rugi dalam Akibat Pencemaran Laut

Metode penelitian yang digunakan dalam penelitian ini adalah metode yiridis normatif, artinya suatu penelitian yang bertumpu pada peraturan perundang-undangan dengan ditopang studi kepustakaan relevan dengan permasalahan dibahas kemudian dianalisis dan disimpulkan dalam penulisan.

Tipe Penelitian Hukum yang digunakan sebagai dasar dalam penelitian ini merupakan penelitian normatif artinya penelitian menggunakan acuan pada pada berbagai peraturan perundang-undangan khususnya yang berkaitan dengan permasalahan penelitian ini. Pendekatan masalah yang digunakan dalam penelitian ini adalah melalui pendekatan perundang-undangan (statute approach), karena selain menggunakan peraturan perundang-undangan yang berlaku yang berkaitan dengan permasalahan, yaitu tanggung gugat pengangkutan minyak terhadap pencemaran laut.

Sumber bahan hukum terdiri dari sumber bahan hukum primer dan bahan hukum sekunder. Bahan hukum primer terdiri dari peraturan perundang-undangan yang mengatur tentang perhubungan laut. Sementara bahan hukum sekunder yaitu segala sumber yang diperoleh dari berbagai bahan hukum, informasi majalah, serta berbagai literatur-literatur baik langsung maupun tidak langsung dalam penulisan penelitian ini.

Prosedur pengumpulan dan pengelolaan bahan hukum dalam penelitian ini dilakukan dengan membaca, mempelaari dan memahami beberapa literatur dan perundang-undangan yang berkaitan dengan pokok permasalahan yang akan 
dipergunakan sebagai pembanding antara teori dan kenyataan yang kemudian diambil suatu keputusan dalam penelitian ini. Analisis penelitian ini dilakukan menggunakan analisis kualitatif dimana langkah-langkah yang ditempuh didasarkan pada logika yuridis, sehingga permasalahannya dapat dijelaskan.

\section{PEMBAHASAN}

\section{Ketentuan Manajemen Keselamatan Pengoperasian Kapal, Pencegahan dan Perlindungan Maritim Akibat Pencemaran Minyak Kapal}

Dalam peraturan keselamatan pengoperasian kapal, dibutuhkan beberapa hal penunjang agar pelaksanaan peraturan-peraturan tersebut dapat berjalan sesuai yang diharapkan demi menjaga keselamatan pengoperasian kapal khususnya pengoperasian kapal minyak. Hal-hal tersebut meliputi, Pertama, International Safety Management (ISM) code, yakni kodifikasi internasional tentang majemen keselamatan pengoperasian kapal dan pencegahan pencemaran sebagaimana yang diatur dalam Bab IX Konvensi SOLAS 1974 yang telah direvisi. Kedua, perusahaan, yaitu perusahaan pemilik atau operator kapal, bentuk organisasi yang diakui yang bertindak dengan/sebagai menejer, pencarter kapal yang menerima tanggung jawab sepenuhnya atas pengoperasian kapal dari pemilik kapal.

Ketiga, Sistem Manajemen Keselatan (SMK), dimana sistem ini merupakan sistem penataan dan pendokumentasian yang memungkinkan personil perusahaan secara aktif menerapkan kebijakan manajemen keselamatan dan perlindungan lingkungan. Keempat, dokumen penyesuaian manajemen keselamatan/ Document of Compliance (DOC) yaitu dokumen pemenuhan yang diterbitkan bagi perusahaan yang telah memenuhi persyaratan peraturan ini. Kelima, sertifikat manajemen keselamatan/ Safety Management Certificate (SMC), adalah dokumen sertifikat yang diterbitkan bagi kapal yang membuktikan bahwa perusahaan dan manajemen diatas kapal berkerja atau terselenggaran sesuai sistem manajemen keselamatan yang disyaratkan. 
Untuk manajemen keselamatan pengoperasian kapal, tidak hanya mengatur kualitas atau memenuhi syarat sebagaimana yang telah disebutkan diatas, tetapi juga sumber daya personil harus memenuhi syarat-syarat sebagaimana diatur dalam Pasal 9 Permenhub Nomor 43 KM Tahun 2008 yang mengatur tentang manajemen keselamatan pengoperasian kapal bahwa sumber daya dan personil harus memenuhi syarat sebagai berikut; (1) Perusahaan harus menjamin bahwa nahkoda; (a) Memenuhi syarat untuk menjadi pemimpin kapal sesuai ketentuan perundangundangan; (b) Memahami sepenuhnya Sistem Manajemen Keselamatan perusahaan; dan; (c) Diberi dukungan yang diperlukan sehingga tugas nahkoda dapat dilaksanakan dengan baik dan aman; (2) Perusahaan harus menjamin bahwa tiap kapal diawaki oleh anak buah kapal yang memenuhi syarat, bersertifikat dan sehat secara medis sesuai dengan persyaratan Nasional dan Internasional; (3) Perusahaan harus menetapkan prosedur untuk memastikan bahwa personil baru dan personil yang dialihkan pada jabatan baru; (4) Perusahaan harus memastikan bahwa seluruh personil yang terlibat dalam Sistem Manajemen Keselamatan Perusahaan memiliki pemahaman yang memadai mengenai mengenai peraturan, kode dan pedoman; (5) Perusahaan harus menetapkan dan mempertahankan prosedur untuk mengindentifikasi setiap pelatihan yang mungkin diperlukan untuk mendukung Sistem Manajemen Keselamatan dan menjamin bahwa pelatihan demikian diberikan kepada seluruh personil yang bersangkutan; (6) Perusahaan harus menetapkan dan mempertahankan prosedur untuk personil kapal menerima informasi yang berkaitan dengan sistem manajemen dalam bahasa yang dimengerti; (7) Perusahaan harus menjamin behwa personil kapal mampu berkomunikasi secara efektif dalam melaksanakan tugasnya.

Selain mengatur manajemen keselamatan pengoperasian kapal, juga diatur mengenai upaya pencegahan pencemaran dari kapal. Menurut Pasal 134 UndangUndang Nomor 17 Tahun 2008 tentang Pelayaran, upaya pencegahan pencemaran dari kapal yaitu sebagai berikut; (1) Setiap kapal yang beroperasi di perairan Indonesia harus memenuhi persyaratan pencegahan dan pengendalian pencemaran; 
(2) Pencegahan dan pengendalian pencemaran ditentukan melalui pemeriksaan dan pengujian; (3) Kapal yang dinyatakan memenuhi persyaratan pencegahan dan pengendalian pencemaran diberikan sertifikat pencegahan dan pengendalian pencemaran oleh Menteri (4) ketentuan lebih lanjut mengenai pencegahan pencemaran dari kapal diatur dengan Peraturan Menteri.

Konvensi Hukum Laut tahun 1982 menentukan keharusan Negara-negara dalam hubungannya dengan terjadinya pencemaran yang berasal dari sumber daratan. Negara-negara harus menetapkan peraturan perundang-undangan untuk mencegah, mengurangi, dan mengendalikan pencemaran lingkungan laut dari sumber daratan termasuk di dalamnya sungai-sungai, kuala-kuala, pipa-pipa dan bangunan pembuangan, dengan memperhatikan ketentuan-ketentuan dan standard-standar internasional yang telah disetujui serta praktik-praktik dan prosedur-prosedur yang dianjurkan (Deplu RI, terjemahan Konvensi Hukum laut 1982).

Ketentuan yang mengatur tentang pencemaran yang berasal dari kegiatan laut yang tunduk pada yurisdiksi nasional adalah Pasal 208 Konvensi Hukum Laut 1982, yang terdiri atas 5 (lima) ketentuan. Ketentuan tentang pencemaran yang berasal dari kegiatan dikawasan diatur di dalam Pasal 209 Konvensi Hukum Laut, yang terdiri dari 2 (dua) ketentuan. Ketentuan tentang pencemaran karena dumping, diatur didalam Pasal 210 Konvensi Hukum Laut 1982 yang terdiri dari 6 (enam) ketentuan. Pencemaran yang berasal dari kendaraan air, diatur dalam Pasal 211 Konvensi Hukum laut 1982, yang terdiri dari 5 (lima ketentuan).

Konvensi Hukum Laut tahun 1982 juga menjamin adanya pemaksaan pentaatan dari peraturan perundang-undangan yang dibuatnya itu untuk ditaati oleh semua Negara atau seluruh pihak yang akan melakukan aktifitas di laut yang menjadi yurisdiksi Negara tersebut.jika aktifitas yang dilakukan oleh Negara atau oleh perorangan mengakibatkan pencemaran laut, maka Negara dalam hal ini dibebani tanggung jawab dan kewajiban ganti rugi kepada Negara yang dirugikan. Mengenai tanggung jawab ganti kerugian ini dapat dilihat pada Pasal 235 Konvensi Hukum Laut 1982 yang menyatakan sebagai berikut; (1) Negara-negara bertanggung jawab 
untuk pemenuhan kewajiban-kewajiban internasional mereka berkenan dengan perlindungan dan pelestarian lingkungan laut. Mereka harus memikul kewajiban ganti rugi sesuai dengan hukum internasional; (2) Negara-negara harus menjamin teresedianya upaya menurut sistem perundang-undangannya untuk diperolehnya ganti rugi yang segera dan memadai atau bantuan lainnya bertalian dengan kerusakan yang disebabkan pencemaran lingkungan laut orang perorangan atau oleh badan hukum dibawah yurisdiksi mereka; (3) Dengan tujuan untuk menjamin ganti rugi yang segera dan memadai bertalian dengan segala kerugian yang disebabkan oleh pencemaran lingkungan laut, Negara-negara harus bekerja sama melaksanakan hukum internasional yang berlaku dan untuk pengembangan selanjutnya hukum internasional yang berkenaan dengan tanggung jawab ganti rugi untuk penaksiran mengenai kompensasi untuk kerusakan serta penyelesaian sengketa yang timbul, demikian pula, dimana perlu, mengembangkan kriteria dan prosedur-prosedur pembayaran ganti rugi yang memadai seperti halnya asuransi wajib atau dana kompensasi (Ibid).

\section{Tanggung Gugat dalam Sistem Pertanggung-Jawaban dan Perjanjian Ganti Rugi Akibat Pencemaran Laut}

Pengaturan tentang tanggung gugat pencemar pada pencemaran lingkungan laut/minyak laut dapat dipenuhi melalui ketentuan hukum nasional maupun hukum internasional. Dibidang hukum internasional, pengaturan tentang pencemaran lingkungan laut oleh tumpahan minyak telah banyak dibentuk. Konvensi internasional yang mengatur secara prinsip ketentuan-ketentuan tentang tanggung gugat pihak-pihak dalam hal terjadinya kcelakaan yang menyebabkan timbulnya pencemaran laut akibat tumpahan minyak yakni The International Convention on Civil Liability For Oil Pollution Damage, yang lebih dikenal dengan Liability Convention 1969, bahwa; (1) ...the owner of a ship at the time of an incident, or where the incident consist of a series of occurrences at the time of the first such occurrence shall be liable for any poluution damage caused by oil which has escaped or been discharged fironr the ship as a result of the incident (Kapal sebagai penyebab 
terjadinya kerusakan atau polusi bertanggung jawab atas akibat yang ditimbulkan yang bersumber dari kappa tersebut); (2) No liability for pollution damage shall attact to the owner if the proves that the damage (tidak ada tanggung jawab akibat polusi oleh pemilik kapal); (a) Resulted from an act of war, hostilities, civil war insurrection of a natural phenomenon of an exceptional inevitable and irresistible (kecelakaan timbul akibat perang, perang saudara, atau bencana alam), or; (b) Was wholly caused by an act of mission done with no cause damage by a third party (dalam peperangan, pihak ketiga bentindak sebagai misi perdamaian), or (3) If the owner proves that the pollution damage resulted wholly act or partially either from an act or omission done with intent to caused damage by the person who suffered the damage or from the negligence of that liability to such person (jika pemilik pantai penyebab polusi akibat kegiatan navigasi sebagai tanggung jawab atas pelayaran).

Pengertian pokok dari hal diatas tersebut adalah bahwa selain dari pada apa yang ditentukan secara khusus, pada saat terjadinya kecelakaan atau bila kecelakaannya terdiri atas suatu rangkaian kejadian, pada saat kejadian yang pertama, pemilik kapal akan bertanggung jawab atas setiap kerusakan yang diakibatkan oleh pencemaran karena minyak yang keluar atau dimuntahkan dari kapal sebagai akibat kecelakaan. Sedangkan pemilik kapal dibebaskan dari kewajiban ganti rugi dalam hal; (1) Jika kecelakaan timbul karena perang, persengketaan bersenjata, perang saudara, pemberontakan atau bencana alam yang tidak dapat dihindarkan; (2) Jika kecelakaan diakibatkan oleh perbuatan atau kelalaian pihak : pihak ketiga dengan maksud untuk menimbulkan kerugian tersebut; (3) Jika kecelakaan ditimbulkan oleh perbuatan atau kelalaian dari korban sendiri, dan Negara pantai yang bertanggung jawab terhadap terpeliharanya mercusuar dan alat-alat navigasi lainnya.

Dalam hukum nasional, terdapat beberapa ketentuan yang mengatur tentang tanggung gugat atau pertanggung jawaban atas pencemaran laut. Ketentuan tentang tanggung gugat ataupun pertanggung jawaban terhadap pihak-pihak dalam hal terjadinya kecelakaan yang menyebabkan timbulnya pencemaran laut akibat tumpahan minyak diatur dalam Keppres Nomor 18 Tahun 1978 yang memberlakukan 
prinsip tanggung gugat mutlak (strict liability) yang juga terdapat dalam kenetuanketentuan Civil Liability Convention 1969. Selain itu dalam Undang-Undang Nomor 4 Tahun 1982 tentang Pokok Pengelolaan Lingkungan Hidup menegaskan :

"dalam beberapa kegiatan yang menyangkut jenis sumber daya tertentu tanggung jawab timbul secara mutlak pada perusak dan atau pencemar pada saat terjadinya perusakan dan atau pencemaran lingkungan hidup yang pengaturannya diatur dalam peraturan perundang-undangan yang bersangkutan"(Supardi, 1985:15)

Dengan adanya Keppres Nomor 18 Tahun 1978 dimana Indonesia telah meratifikasi Konvensi Internasional tentang Tanggung Gugat sipil atas kerugian akibat pencemaran laut oleh minyak. Pada tanggal 16 September 1982, Dirjen Perhubungan Laut menyatakan bahwa sertiap kapal yang memasuki perairan Indonesia dan mengangkut minyak sebagai muatan dalam jumlah lebih besar dari 2.000 ton harus memiliki sertifikat dan jaminan ganti rugi pencemaran laut. Dengan adanya sertifikat ganti rugi pencemaran laut bagi kapal-kapal pengangkut minyak yang mempunyai muatan lebih dari 2.000 ton, dianggap belum memenuhi jumlah kerugian para pihak yang dirugikan akibat pencemaran minyak, yang dinilai ganti kerugian tersebut tidak diberikan ganti rugi ekologis.

Kendati demikian, pada dasarnya pemilik kapal dibebani kewajiban-kewajiban. Pemilik kapal yang mengangkut lebih dari 2.000 ton secara curah sebagai muatan, wajib memiliki asuransi atau jaminan keuangan lainnya mislanya jaminan bank, yang dengan itu agar kapal tersebut dapat diterbitkan Sertifikat Dana Jamina Ganti Rugi Pencemaran laut yang diakui oleh Negara peserta Konvensi Internasional dan mempunyai kekuatan hukum tetap. Dengan demikian gugatan ganti rugi dapat diajukan langsung kepada pembeli atau perusahaan asuransi yang dimaksud.

Undang-undang Nomor 21 tahun 1992 lebih khusus lagi mengatur tanggung gugat secara perdata bagi pencemaran yang bersumber dari kapal (baik selama pelayaran maupun selama melaksanakan kegiatan lain di perairan maupun Bandar) dan sanksi pidana. Pasal 65, disebutkan setiap kapal dilarang membuah limbah bila tidak memenuhi syarat. Sementara itu pada Pasal 68 disebutkan; (1) Pemilik atau 
operator kapal bertanggung jawab terhadap pencemaran yang bersumber dan kapalnya; (2) Untuk memenuhi tanggung jawab dimaksud, pemilik atau operator kapal wajib mengasuransikan tanggung jawabnya; (3) Ketentuan dimaksud ayat (a) dan (b) diatur lebih lanjut dengan Peraturan Pemerintah. Pada Pasal 19, disebutkan "barang siapa membuang limbah dipidana penjara maksimal 5 (lima) tahun atau denda maksimal Rp. 12.000.000,00 (dua belas juta rupiah) apabila mengakibatkan rusaknya dan atau tercemarnya lingkungan dipidana penjara maksimal 10 (sepuluh) tahun atau denda maksimal Rp. 240.000.000,00 (dua ratus empat puluh juta rupiah)

\section{SIMPULAN}

Terjadinya pencemaran laut akibat minyak atau limbah dari kapal salah satu faktor adalah kurangnya tanggung jawab pemilik kapal terhadap pemenuhan persyaratanpersyaratan teknis, baik dari fisik kapal maupun ketentuan administrasi sesuai peraturan perundang-undangan yang berlaku, baik secara nasional maupun internasional dan juga masih terjadi penyimpangan hukum dalam hal kebijakan terhadap suatu peraturan yang berpotensi terjadinya pencemaran laut. Akibat pencemaran laut yang berasal dari kapal maupun kegiatan ekplorasi pengeboran lepas pantai dalam bentuk minyak melalui pengangkut oleh kapal pengangkut minyak, konsekuensinya adalah perlunya tanggung jawab terhadap akibat yang ditimbulkan karena itu, Undang-Undang telah mengatur sejumlah sanksi yang harus ditanggung oleh setiap penyebab terjadinya pencemaran laut baik penyelenggara pengakutan minyak maupun pemilik kapal pengangkut minyak.

\section{DAFTAR PUSTAKA}

Abdurahman, 1986, Pengantar Hukum Lingkungan Indonesia, Alumni, Bandung. Departemen Perhubungan Direktorat Jenderal Perhubungan Laut, 2002, Buku Materi Penyuluhan Keselamatan Kapal.

Departemen Perhubungan, 2007, Materi Penyegaran MI "B” Dalam Rangka Pengukuhan Angkatan II (Keputusan Menteri Perhubungan), Jakarta.

Dirjen Perhubungan Laut, Direktorat Perkapalan dan Kepelautan, 2009, Materi Temu Teknis Bidang Kelaiklautan Kapal. 
Keppres No. 65 Tahun 1980 tenang Ratifikasi "International Convention for the Safety of life at Sea 1974".

Keppres No. 177 Tahun 2000 tentang Susunan Organisasi dan Tugas Departemen, sebagaimana telah diubah terakhir dengan Keputusan Presiden Nomor 38 Tahun 2001.

Keppres No. 102 tentang Kedudukan, Tugas, Fungsi, Kewenangan, Susunan Organisasi dan Tata Kerja Departemen.

Kepmenhub No. KM 43 Tahun 2005 tentang Organisasi dan Tata Kerja Departemen Perhubungan

Komar Kantaatmaja, 1982, Bunga Rampai Hukum Lingkungan Laut Internasional, Alumni, Bandung, 1981.

, 1981, Ganti Rugi Internasional Pencemaran Minyak di Laut, Alumni, Bandung.

MARPOL 73/78, 1991, Consolidated Edition, IMO, London

Mochtar Danusaputra, 1978, Hukum Pencemaran dan Usaha Merintis Pembangunan Hukum Pencemaran Nusantara, Litera, Bandung.

Purwosutjipto (III), 1987, Pengertian Pokok Hukum Dagang Indonesia, Djambatan, Jakarta.

, 1983, Pengertian Pokok Hukum Dagang di Indonesia, Djambatan, Jakarta.

Permenhub No. 4 Tahun 2005 tentang Pencegahan Pencemaran Kapal

Resolusi IMO No. A 741 (18) tahun 1993 tentang International Safety Management (ISM) Code.

Resolusi IMO No. A 739 (18) tahun 1993 tentang Guidelines for the Authorization of Organization acting on Behalf of the Administration.

Resolusi IMO No. A 913 (22) tahun 2002 tentang Revised Guidelines on Implementation of the International Safety Management (ISM) Code by Administration.

Soekardono, Hukum Dasar Indonesia, Rajawali, Jakarta, 1986.

Subekti dan Tjitrosudibio, 1979, Kitab Undang-Undang Hukum Dagang dan Undang-Undang Kepailitan, Pradya Paramitha, Jakarta , 1979, Kitab Undang-Undang Hukum Perdata, Pradya Paramitha, Jakarta.

Sudjatmiko, 1979, Pokok-Pokok Pelayaran Niaga, Akademika Pressindo, Jakarta.

Supardi, I, 1985, Lingkungan Hidup dan Kelestariannya, Alumni, Bandung. 